\title{
Article \\ Application of Deep Neural Network to Predict the High-Cycle Fatigue Life of AISI 1045 Steel Coated by Industrial Coatings
}

\author{
${\text { Erfan Maleki }{ }^{1} \text { (D), Okan Unal }}^{2,3}$ (D), Seyed Mahmoud Seyedi Sahebari ${ }^{4}$, Kazem Reza Kashyzadeh ${ }^{5, *(D)}$ \\ and Igor Danilov 5
}

check for updates

Citation: Maleki, E.; Unal, O.; Seyedi Sahebari, S.M.; Reza Kashyzadeh, K.; Danilov, I. Application of Deep Neural Network to Predict the High-Cycle Fatigue Life of AISI 1045 Steel Coated by Industrial Coatings. J. Mar. Sci. Eng. 2022, 10, 128. https:// doi.org/10.3390/jmse10020128

Academic Editor: José A.F.O. Correia

Received: 13 December 2021

Accepted: 16 January 2022

Published: 19 January 2022

Publisher's Note: MDPI stays neutral with regard to jurisdictional claims in published maps and institutional affiliations.

Copyright: (C) 2022 by the authors. Licensee MDPI, Basel, Switzerland. This article is an open access article distributed under the terms and conditions of the Creative Commons Attribution (CC BY) license (https:// creativecommons.org/licenses/by/ $4.0 /)$
1 Mechanical Engineering Department, Politecnico di Milano, 20156 Milan, Italy; erfan.maleki@polimi.it

2 Mechanical Engineering Department, Karabuk University, Karabuk 78050, Turkey; unalokan78@gmail.com

Modern Surface Engineering Laboratory, Karabuk University, Karabuk 78050, Turkey

4 Department of Mechanical and Manufacturing Engineering, Ontario Tech University, Oshawa, ON L1G 0C5, Canada; Seyedmahmoud.seyedisahebari@ontariotechu.net

5 Department of Transport, Academy of Engineering, Peoples' Friendship University of Russia (RUDN University), 6 Miklukho-Maklaya Street, 117198 Moscow, Russia; danilov-ik@rudn.ru

* Correspondence: reza-kashi-zade-ka@rudn.ru or kazem.kashyzadeh@gmail.com

\begin{abstract}
In this study, deep learning approach was utilized for fatigue behavior prediction, analysis, and optimization of the coated AISI 1045 mild carbon steel with galvanization, hardened chromium, and nickel materials with different thicknesses of 13 and $19 \mu \mathrm{m}$ were used for coatings and afterward fatigue behavior of related specimens were achieved via rotating bending fatigue test. Experimental results revealed fatigue life improvement up to $60 \%$ after applying galvanization coat on untreated material. Obtained experimental data were used for developing a Deep Neural Network (DNN) modelling and accuracy of more than $99 \%$.was achieved. Predicted results have a fine agreement with experiments. In addition, parametric analysis was carried out for optimization which indicated that coating thickness of $10-15 \mu \mathrm{m}$ had the highest effects on fatigue life improvement.
\end{abstract}

Keywords: fatigue life; coating; deep neural network; optimization; prediction

\section{Introduction}

Most of the used components in some major industries such as marine and offshore industries which primarily comprises the offshore oil and gas and the offshore wind energy industries are affected by the repeated applied loadings that make fatigue failure. Moreover, the corrosion phenomenon is an unavoidable factor for the failure of structures in the vicinity of water, especially seawater due to its salinity [1,2]. However, combination of fatigue and corrosion simultaneously can afford faster failure and generally, amounts of damages caused by corrosion fatigue are higher [3]. Therefore, considering effective approaches to improve the corrosion resistance and fatigue have critical roles in this area [4,5]. To improve the corrosion resistance of conventionally manufactured materials (specially steels), varieties of treatments can be performed such as shot peening [6-14], carburizing [15-17], and plating [18-22]. In addition, rather than conventional materials, recently different postprocessing methods were also applied on the additively manufactured metallic materials as well to improve the mechanical properties [23-32].

Plating due its low cost, mostly used by providing a protective layer of corrosionresistant material in the outer surface of the components that has contact with the corrosive environments. In electroplating as one of widely used methods of plating, an ionic metal is prepared with electrons to make a non-ionic coating on a regraded substrate by using chemical solution [33]. Because of initiation of micro-cracks in the coat layer by apply loading and afterward it's interpenetration to the substrate, fatigue life of the coated material, specifically steels, might be reduced although the corrosion resistance was improved [34]. It is approved by many researches that different coatings such as nickel, hardened chromium, 
warm galvanization, and titanium can be improved the corrosion resistance [35-38] but few works were carried out to study the effects of coatings on fatigue behavior of the mantellic materials $[39,40]$.

On the other hand, recently artificial intelligence-based approaches such as neural networks (NNs) are extensively implemented to analyze and optimize multi-objective and complex problems [41-44]; as well as their wide applications in fatigue life estimation [45-50]. Based on the available data in the literature different types of NNs were utilized for fatigue behavior prediction and analyses [51-57]. It should be mentioned that there are also different methods for fatigue life assessment such as XFEM [58,59] and phase field method [60,61]. By applying NN modelling or other approaches such as XFEM rather than fatigue life prediction, other types of analyses such as parametric and sensitivity analyses can be carried out by generating corresponded model function or further finite element analyses. However, by using other common methods such S-N or Manson-coffin curves only life predictions can be obtained.

In general, a neural network consists of three major layers: input, hidden, and output layers [62]. As the primary generation of artificial neural networks, shallow neural networks (SNNs) that have 1 or 2 hidden layers were mostly used in simulations of the ill-defined problems [63]. However, it is approved by developing Deep Neural Network (DNN) that has more hidden layers (more than 2), higher accuracy in the predicted results can be obtained with same or smaller data set $[64,65]$. The NNs are the most frequently employed machine learning approach for fatigue life prediction in the last decade [66]. A major reason for the popularity of the application of NNs on fatigue behavior analysis is that NNs are mostly utilized for universal function approximation. NNs have significant self-learning properties, adaptivity, fault tolerance, nonlinearity, and flexibility of nonlinear mapping [67]. Therefore, as phenomenon of fatigue is highly sensitive to various parameters including material, loading, temperature, humidity, vibration etc., NNs can be applied to all fatigue analysis. On the other hand, as reported in several recent studies [68,69], applications of DNN based modelling of fatigue behavior attracts lots of attention lately due to their higher performance and accuracy compared to the SNNs [70,71]. In addition, it should be mentioned that applications of NN-based models for fatigue behavior analyses are investigated in the comprehensive review study carried out by Chen and Liu [72].

Following the authors previous studies $[47,73]$ which surveyed the applications of SNNs on fatigue life prediction of the coated carbon steel, in this study, influences of three different coatings of nickel, hardened chromium, and warm galvanization on fatigue behavior of the AISI 1045 mild carbon steel which has extensive applications in different industries due its cost and properties, were investigated experimentally and a DNN model was developed for prediction of fatigue life of the coated steel with different coatings thicknesses and amplitude stresses.

\section{Experimental Study}

Fatigue test specimens (as shown in Figure 1a) based on the BS3518 standard [59] were prepared using AISI 1045 carbon steel with chemical composition of $0.45 \mathrm{C}, 0.8 \mathrm{Mn}$, $0.04 \mathrm{P}, 0.05 \mathrm{~S}$ and Bal. Fe (\% weight). The used material had yield and ultimate stresses of 475 and $515 \mathrm{MPa}$ respectively. AISI 1045 is widely employed in different engineering components such as tools, railway wheels, and offshore structures due to its good properties and low cost [60-62]. Three sets of specimens were considered for each desired coating, including one control specimen without coating (as-received) and two others with different coating thickness. Fatigue tests were performed via rotating cantilever beam equipment (as presented in Figure $1 b$ ) with stress ratio of $R=-1$, frequency of $58 \mathrm{~Hz}$, room temperature, $50 \%$ humidity, and pure bending load with stress amplitude range of 330-450 MPa in all considered sets of specimens. To obtain S-N curves, in each regarded sets 13 samples were utilized. Three coatings of nickel, hardened chromium, and warm galvanization, with thicknesses of 13 and $19 \mu \mathrm{m}$ were plated on the steel substrate via electroplating in same 
conditions of humidity, temperature, etc. Images of Scanning Electron Microscopy (SEM) of the coated specimens with considered thicknesses are presented in Figure 1c.

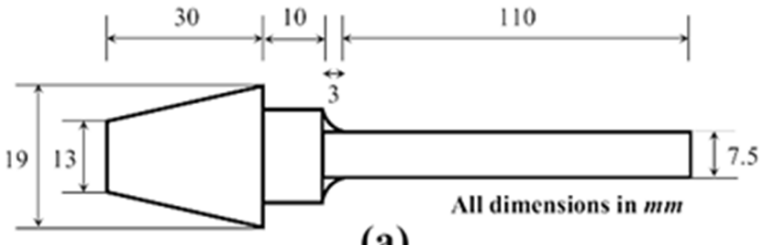

(a)

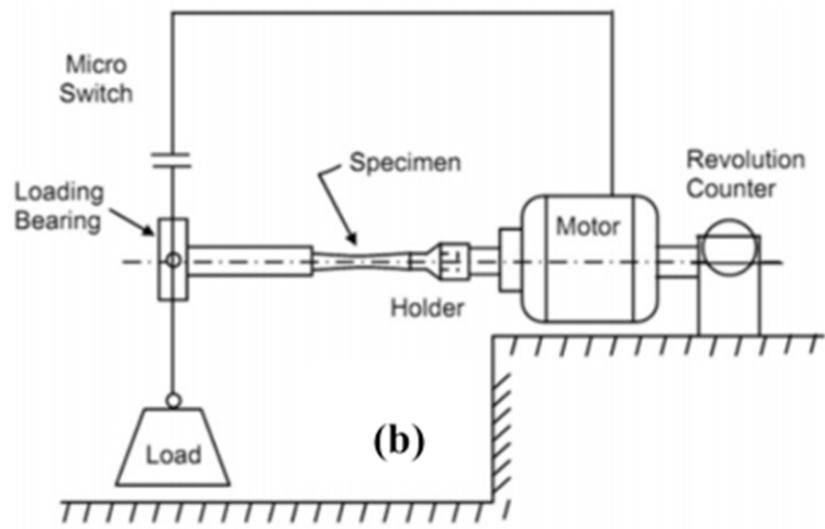

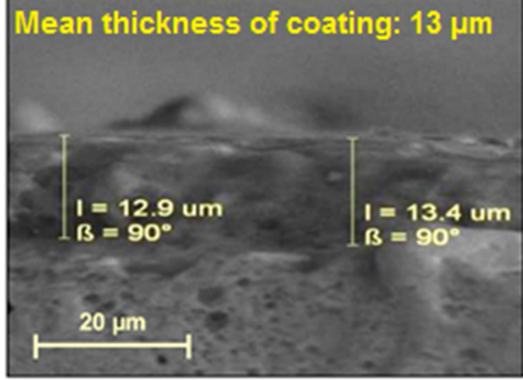

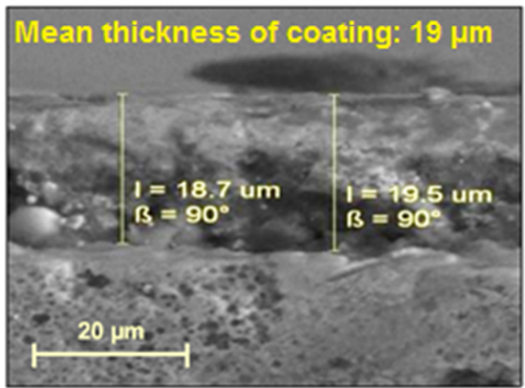

(c)

Figure 1. (a) Fatigue test specimen and (b) Schematic illustration of cantilever rotating bending fatigue equipment used in this study. (c) Observed coating thicknesses by SEM, from up to bottom 13 and $19 \mu \mathrm{m}$, respectively.

Obtained S-N curves of the coated AISI 1045 steel with different coatings as results of fatigue tests is presented in Figure 2 [41,63]. The results of fatigue experiments reveal that fatigue life improves in the coated specimens by warm galvanization in both thicknesses of 13 and $19 \mu \mathrm{m}$. Also, in the coated specimen by nickel with $13 \mu \mathrm{m}$ thickness. Nickel coating with19 $\mu \mathrm{m}$ thickness approximately has no effects on variation of fatigue life. However, fatigue life of coated specimens with hardened chromium in both considered thicknesses is reduced. Considering stress level of $330 \mathrm{MPa}$, the results reveal that after applying coatings on the untreated material, the fatigue behavior can be improved up to $40-60$ and $5-50 \%$ in the coated specimens with warm galvanization and nickel, respectively. 


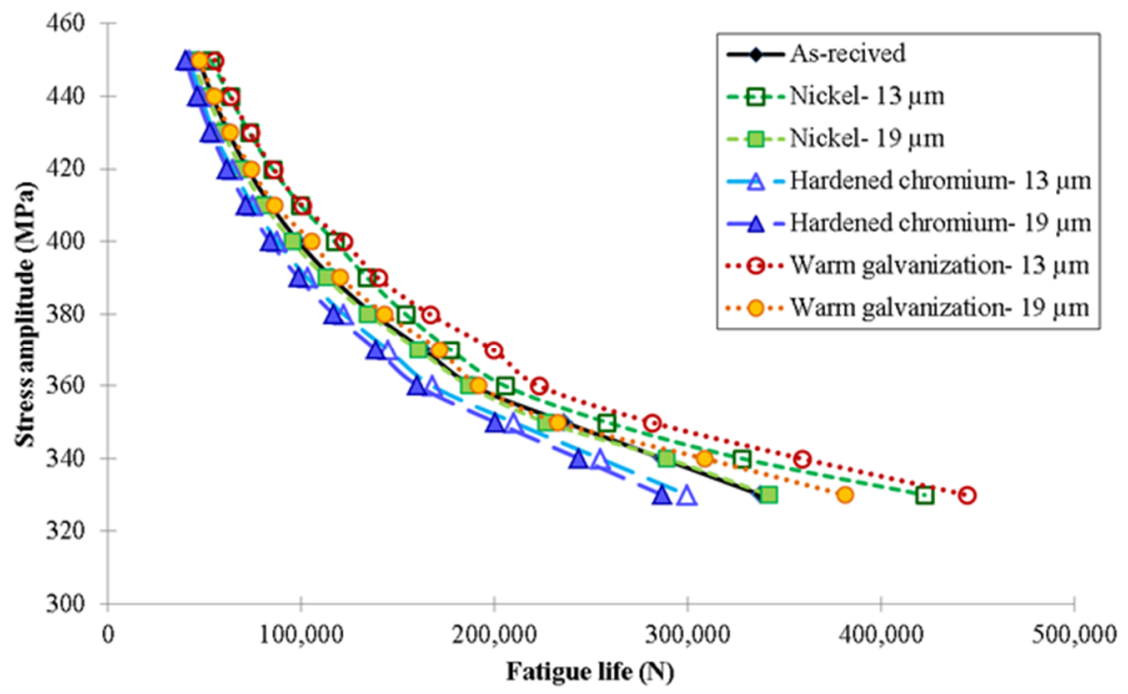

Figure 2. S-N curves of the coated AISI 1045 steel with different coatings and the correspondence thicknesses.

\section{Deep Neural Network}

In this study, uncoated AISI 1045 steel specimen was considered as control specimen; thus, the coated specimens with different thicknesses and materials revealed the effects of applied post-treatment under fatigue loading. Therefore, two parameters were considered for inputs of the NNs modelling; one is related to the material and the other one is related to the fatigue test. The difference of the treated materials rather than the coatings material is the thickness of each coating which considered as one of the inputs. Also, a major parameter of stress amplitude which is related to the conditions of fatigue loading was also regarded as inputs. Strong correlation of these two parameters as the main variables of this study with fatigue behavior can be clearly seen in the obtained S-N curves of the different sets of specimens. As it mentioned, fatigue behavior was investigated at 13 different stress levels and with considering of coating three thicknesses of 0 (as-received specimens), 13, and $19 \mu \mathrm{m}$ for coatings, there exist 39 samples for each of the regarded coatings materials that 30 of them were used for training and the remained 9 samples, which not employed during training step, were used for network testing. Overall, 77 and $23 \%$ of obtained experimental data was used for networks training and testing processes, respectively. Employed methodology in this study is presented in Figure 3a (similar methodology to the one used by Maleki et al. $[63,65])$. Different SNNs and DNNs by trial-and-error approach were developed; Figure $3 \mathrm{~b}$ depicts the architecture of the DNN with four hidden layers that $\mathrm{w}, \mathrm{b}$ and $\mathrm{f}$ represent the weight matrixes, bias vectors, and transfer function in each related layer, respectively. It is well known that number of neurons as computational nodes of neural networks, have critical role on the efficiency of applied models [74]. Accuracy of the predicted results of networks which determined via correlation coefficient (R2) was gathered as the factor of efficiency of each developed network. Value of (R2) was calculated as follows [75]:

$$
R^{2}=\frac{\sum_{i=1}^{n}\left(f_{E X P, i}-F_{E X P}\right)\left(f_{A N N, i}-F_{A N N}\right)}{\sqrt{\sum_{i=1}^{n}\left(\left(f_{E X P, i}-F_{E X P}\right)^{2}\left(f_{A N N, i}-F_{A N N}\right)^{2}\right)}}
$$

where, $n$ is the number of fed samples, $f_{E X P}$ and $f_{A N N}$ represent the experimental and predicted values, respectively. The values of $f_{E X P}$ and $f_{A N N}$ were determined as follows [76]:

$$
F_{E X P}=\frac{1}{n} \sum_{i=1}^{n} f_{E X P, i}
$$




$$
F_{A N N}=\frac{1}{n} \sum_{i=1}^{n} f_{A N N, i}
$$

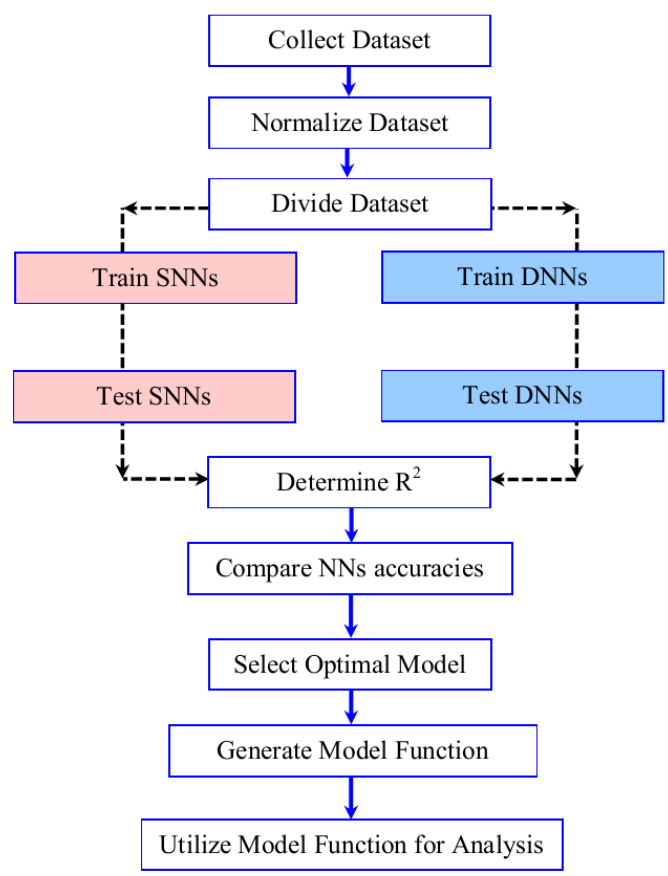

(a)

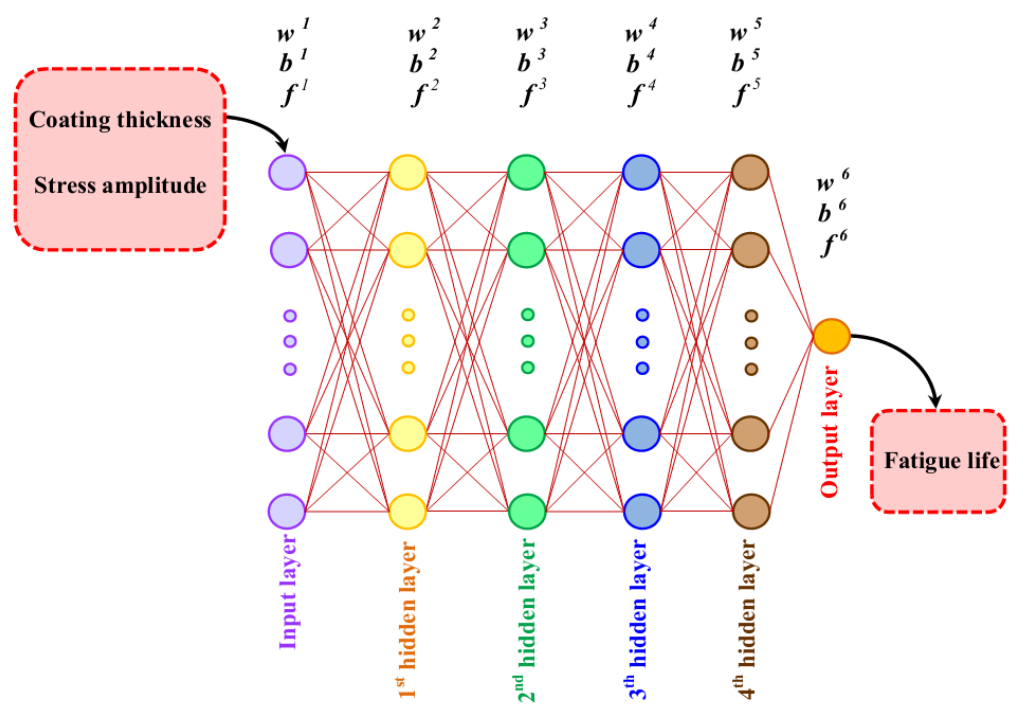

(b)

Figure 3. (a) Employed methodology and (b) Schematic of a DNN with four hidden layers.

\section{Results and Discussion}

Accuracy of the results of several developed SNNs with 1 and 2 hidden layers with different number of neurons in each layer of them for nickel coated specimens is compared in Figure 4a. It can be seen that in the SNNs, in most of the cases by increasing the number of neurons, the efficiency of the network is become higher. Figure $4 \mathrm{~b}$ illustrates a comparison between the accuracy of the developed SNNs and DNNs with highest performance for all of the coating materials. From this figure, by implementation of a DNN with structure of 2-36-18-18-9-1, learning rate of 0.185, and Logaritmic Sigmod tarnsfer function, accuracy of the predicted results of fatigue life for all of the coated specimens for each testing and 
training steps can be reached to approximately 0.99 , which is quite acceptable. Comparison of the predicted and experimentally values of fatigue life for training and testing steps is revealed in Figure 5.
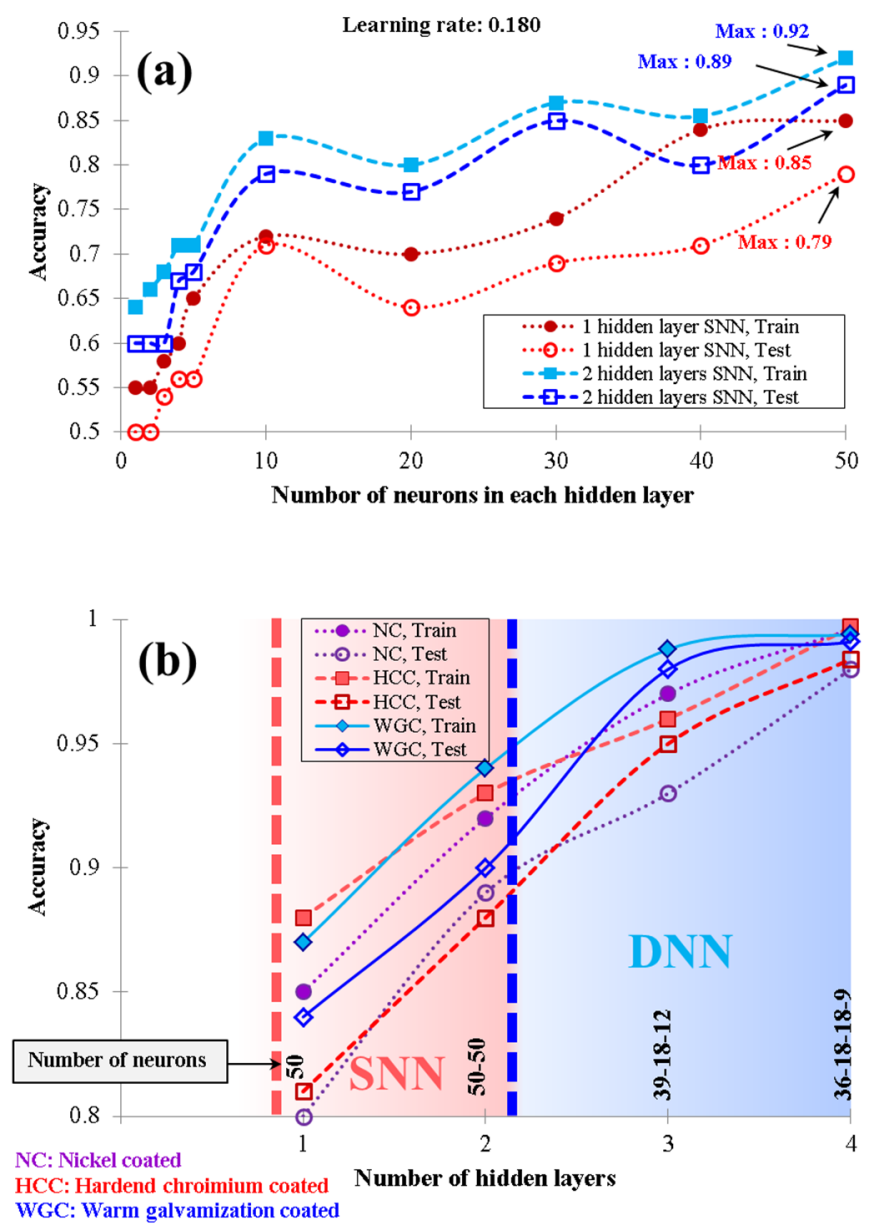

Figure 4. (a) Performance of the developed SNNs with considering the number of neurons in each layer and (b) Comparison of the accuracy of developed SNNs and DNNs.
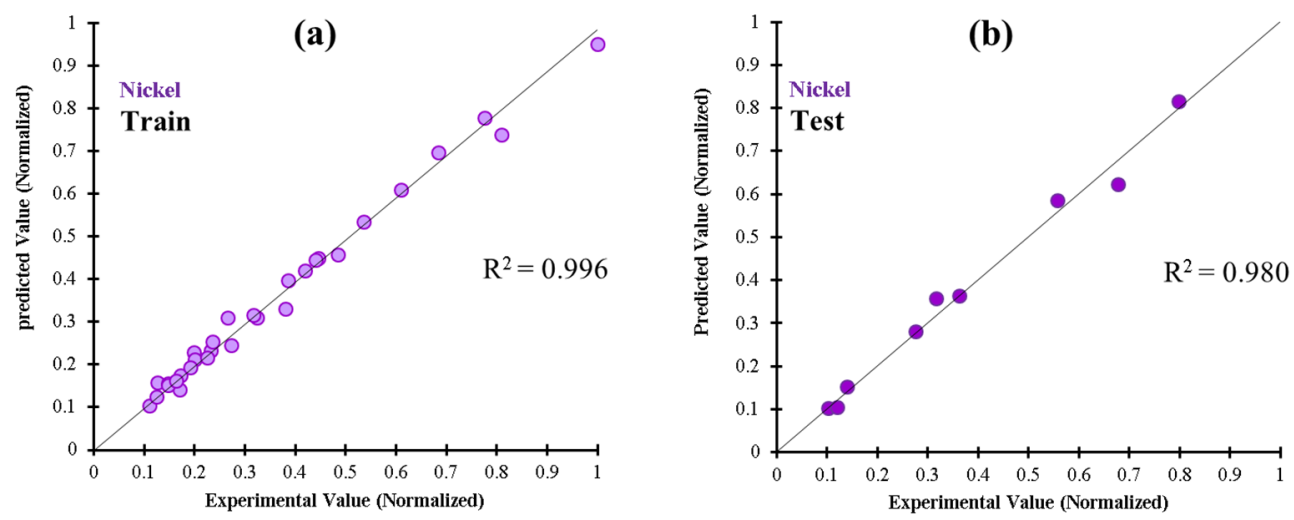

Figure 5. Cont. 

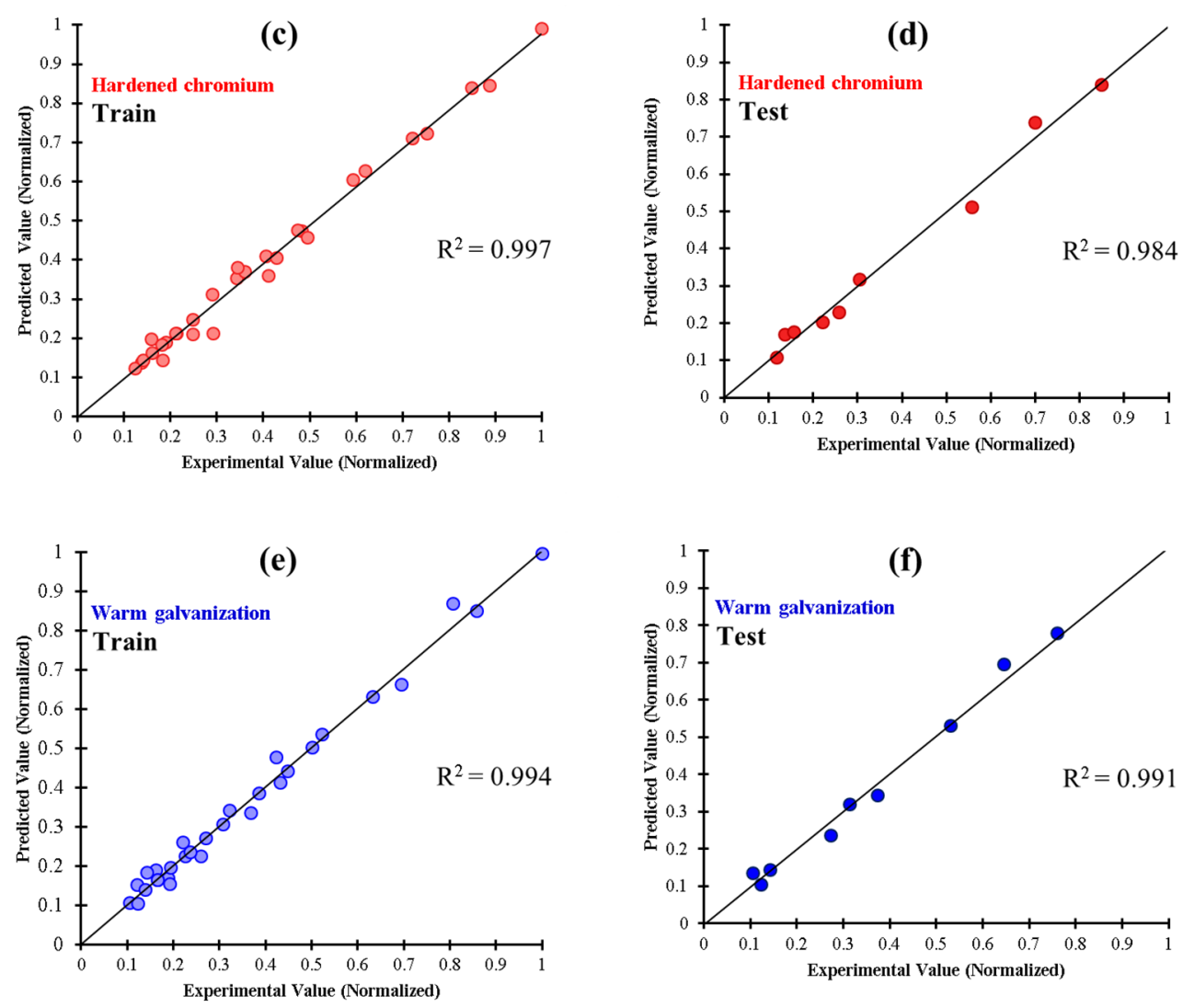

Figure 5. Comparison of the predicted and experimental values of fatigue life for training and testing steps considering the coated materials, including $(\mathbf{a}, \mathbf{b})$ Nickel, $(\mathbf{c}, \mathbf{d})$ Hardened chromium, and $(\mathbf{e}, \mathbf{f})$ Warm galvanization.

To clearly observe the differences between the experimental and predicted results through developing DNNs, combined results of training and testing processes for all coating materials are shown in Figure 6. The results reveal highly acceptable and very low data scattering in the obtained results.

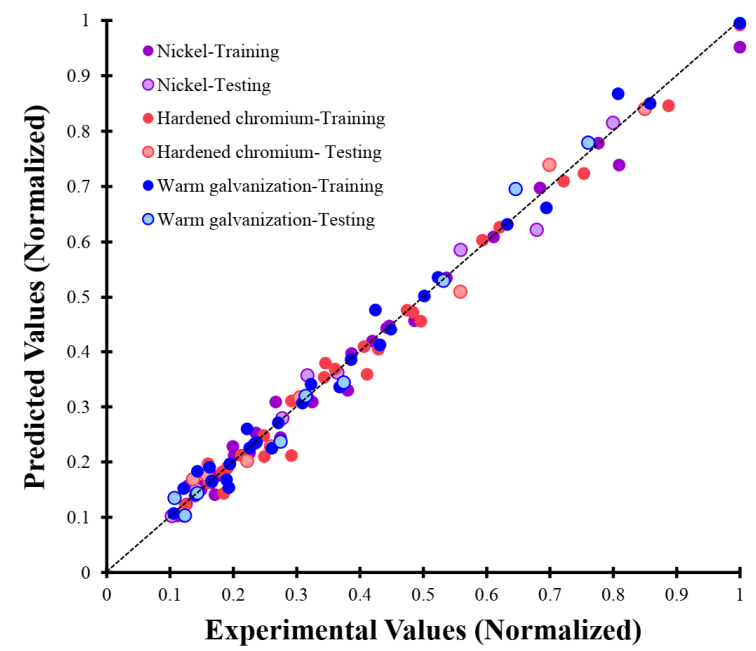

Figure 6. Combined results of training and testing processes for all coating materials comparing the experimental and predicted values. 
Relevant model function of a DNN with 6 layers can be determined by the following equation:

$$
O(o(1))=a^{6}=f^{6}\left(w^{6} f^{5}\left(w^{5} f^{4}\left(w^{4} f^{3}\left(w^{3} f^{2}\left(w^{2} f^{1}\left(w^{1} i+b^{1}\right)+b^{2}\right)+b^{3}\right)+b^{4}\right)+b^{5}\right)+b^{6}\right)
$$

where $a^{1}$ to $a^{5}$ represent the outputs of the first to fifth layer, respectively; $a^{6}$ is the sixth layer output which is equal to the function $O(o(1))$. Function of $o(1)$ expresses fatigue life.

Although in the used data set which fed to the network, there were only 3 and 13 values for coatings thicknesses and stress amplitude, respectively, by using generated model function, parametric analyses can be carried out for the whole interval of the input parameters as shown in Figure 7. According to the DNN results, AISI 1045 steel coated by nickel and warm galvanization with coating thicknesses of 10 to $15 \mu \mathrm{m}$ have the highest effects on fatigue life improvement and the thickness values lower and higher than the mentioned interval have not any considerable effects on the variation of the fatigue life. However, in the hardened chromium coated material, fatigue life decreases by increasing of coating thickness.

(a)

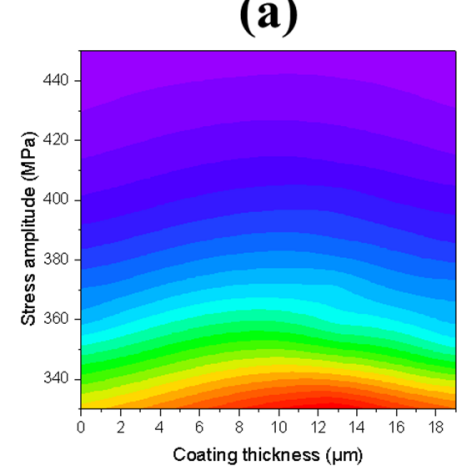

Coating thickness $(\mu \mathrm{m})$

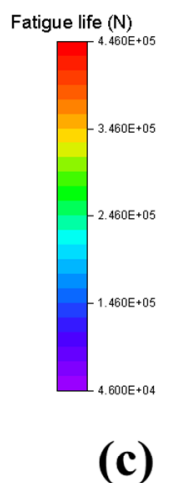

(c)

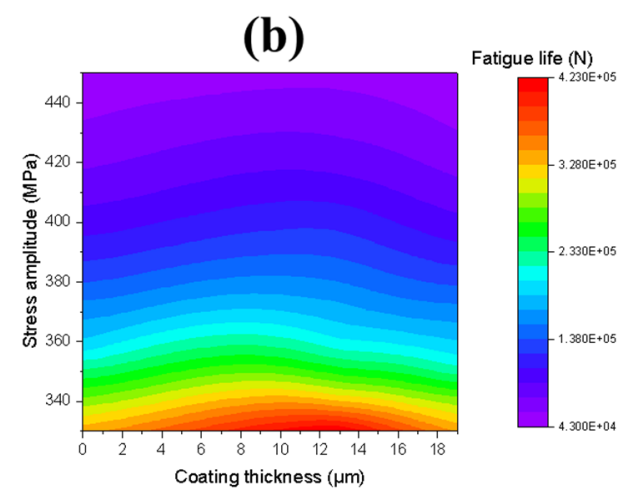

Fatigue life $(\mathrm{N})$

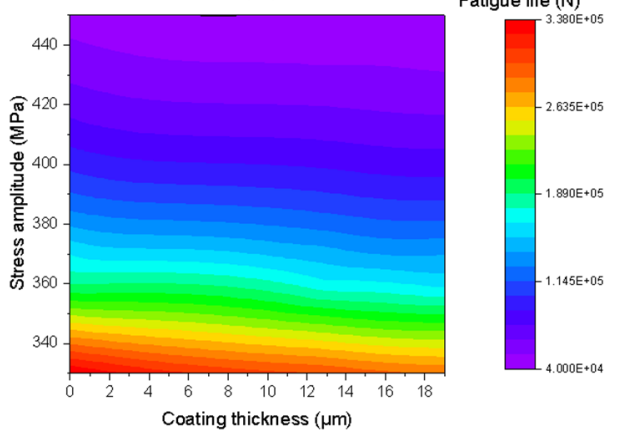

Figure 7. 2D contours of influences of coating thickness and stress amplitude on fatigue life of AISI 1045 steel for coating materials of (a) Nickel, (b) Warm galvanization, and (c) Hardened chromium.

\section{Conclusions}

In the present study, influences of different conventional industrial coatings, including nickel, hardened chromium, and warm galvanization which are usually used for the improvements of the corrosion resistance, were investigated on fatigue life of the coated AISI 1045 carbon steel. Experimental results revealed that coatings of nickel and warm galvanization with a thickness of $13 \mu \mathrm{m}$ improve the fatigue life. Moreover, using hardened chromium coating leads to reduce the fatigue life of the AISI 1045 steel. Afterward, the process was modeled and analyzed via SNNs and DNNs that based on the obtained results of R2, DNN has higher performance rather than the SNN. DNN results illustrate that highest fatigue life of coated steel with nickel and warm galvanization can be obtained in the thicknesses of 10-15 $\mu \mathrm{m}$ and also by employing hardened chromium as coating, by increasing of the thickness the fatigue life decreases. Eventually, it can be concluded that 
DNN that has more efficiency than SNN can be used for prediction and analysis of the fatigue life of coated materials finely.

Author Contributions: Conceptualization, E.M. and K.R.K.; methodology, E.M., O.U. and S.M.S.S.; software, E.M. and O.U.; validation, E.M., O.U. and K.R.K.; formal analysis, E.M., O.U. and S.M.S.S.; investigation, E.M., O.U., K.R.K., S.M.S.S. and I.D.; resources, E.M., O.U., K.R.K., S.M.S.S. and I.D.; data curation, E.M. and K.R.K.; writing - original draft preparation, E.M., O.U. and S.M.S.S.; writingreview and editing, E.M., K.R.K. and I.D.; visualization, E.M.; supervision, E.M., O.U. and K.R.K.; project administration, K.R.K.; funding acquisition, K.R.K. and I.D. All authors have read and agreed to the published version of the manuscript.

Funding: This research received no external funding.

Institutional Review Board Statement: Not applicable.

Informed Consent Statement: Informed consent was obtained from all subjects involved in the study.

Data Availability Statement: The data that support the findings of this study are available from the corresponding author upon reasonable request.

Acknowledgments: This paper has been supported by the RUDN University Strategic Academic Leadership Program.

Conflicts of Interest: The authors declare no conflict of interest.

\section{References}

1. Amiri, N.; Shaterabadi, M.; Reza Kashyzadeh, K.; Chizari, M. A Comprehensive Review on Design, Monitoring, and Failure in Fixed Offshore Platforms. J. Mar. Sci. Eng. 2021, 9, 1349. [CrossRef]

2. Abdollahnia, H.; Hadi, M.; Elizei, A.; Kashyzadeh, K.R. Multiaxial Fatigue Life Assessment of Integral Concrete Bridge with a Real-Scale and Complicated Geometry Due to the Simultaneous Effects of Temperature Variations and Sea Waves Clash. J. Mar. Sci. Eng. 2021, 9, 1433. [CrossRef]

3. Makhlouf, A.S.H. Handbook of Smart Coatings for Materials Protection; Woodhead Publishing: Cambridge, UK, 2014; ISBN 9780857096883.

4. Maleki, E.; Bagherifard, S.; Bandini, M.; Guagliano, M. Surface post-treatments for metal additive manufacturing: Progress, challenges, and opportunities. Addit. Manuf. 2021, 37, 101619. [CrossRef]

5. Maleki, E.; Maleki, N.; Fattahi, A.; Unal, O.; Guagliano, M.; Bagherifard, S. Mechanical characterization and interfacial enzymatic activity of AISI 316L stainless steel after surface nanocrystallization. Surf. Coat. Technol. 2021, 405, 126729. [CrossRef]

6. Unal, O.; Maleki, E.; Varol, R. Effect of severe shot peening and ultra-low temperature plasma nitriding on Ti-6Al-4V alloy. Vacuum 2018, 150, 69-78. [CrossRef]

7. Maleki, E.; Unal, O.; Reza Kashyzadeh, K. Efficiency Analysis of Shot Peening Parameters on Variations of Hardness, Grain Size and Residual Stress via Taguchi Approach. Met. Mater. Int. 2019, 25, 1436-1447. [CrossRef]

8. Maleki, E.; Unal, O.; Kashyzadeh, K.R.K.R. Effects of conventional, severe, over, and re-shot peening processes on the fatigue behavior of mild carbon steel. Surf. Coat. Technol. 2018, 344, 62-74. [CrossRef]

9. Amanov, A.; Karimbaev, R.; Maleki, E.; Unal, O.; Pyun, Y.S.Y.-S.; Amanov, T. Effect of combined shot peening and ultrasonic nanocrystal surface modification processes on the fatigue performance of AISI 304. Surf. Coat. Technol. 2019, 358, 695-705. [CrossRef]

10. Hashemi, B.; Rezaee Yazdi, M.; Azar, V. The wear and corrosion resistance of shot peened-nitrided 316L austenitic stainless steel. Mater. Des. 2011, 32, 3287-3292. [CrossRef]

11. Maleki, E.; Bagherifard, S.; Unal, O.; Bandini, M.; Farrahi, G.H.; Guagliano, M. Introducing gradient severe shot peening as a novel mechanical surface treatment. Sci. Rep. 2021, 11, 22035. [CrossRef] [PubMed]

12. Maleki, E.; Unal, O.; Guagliano, M.; Bagherifard, S. The effects of shot peening, laser shock peening and ultrasonic nanocrystal surface modification on the fatigue strength of Inconel 718. Mater. Sci. Eng. A 2021, 810, 141029. [CrossRef]

13. Maleki, E.; Unal, O.; Reza Kashyzadeh, K. Influences of Shot Peening Parameters on Mechanical Properties and Fatigue Behavior of 316 L Steel: Experimental, Taguchi Method and Response Surface Methodology. Met. Mater. Int. 2021, 27, 4418-4440. [CrossRef]

14. Unal, O.; Maleki, E.; Karademir, I.; Husem, F.; Efe, Y.; Das, T. Effects of conventional shot peening, severe shot peening, re-shot peening and precised grinding operations on fatigue performance of AISI 1050 railway axle steel. Int. J. Fatigue 2022, 155, 106613. [CrossRef]

15. Nikam, V.V.; Reddy, R.G.; Collins, S.R.; Williams, P.C.; Schiroky, G.H.; Henrich, G.W. Corrosion resistant low temperature carburized SS 316 as bipolar plate material for PEMFC application. Electrochim. Acta 2008, 53, 2743-2750. [CrossRef]

16. Martin, F.J; Natishan, P.M.; Lemieux, E.J.; Newbauer, T.M.; Rayne, R.J.; Bayles, R.A.; Kahn, H.; Michal, G.M.; Ernst, F.; Heuer, A.H. Enhanced corrosion resistance of stainless steel carburized at low temperature. Proc. Metall. Mater. Trans. A Phys. Metall. Mater. Sci. 2009, 40, 1805-1810. [CrossRef] 
17. Sharghi-Moshtaghin, R.; Kahn, H.; Ge, Y.; Gu, X.; Martin, F.J.; Natishan, P.M.; Rayne, R.J.; Michal, G.M.; Ernst, F.; Heuer, A.H. Low-temperature carburization of the ni-base superalloy IN718: Improvements in surface hardness and crevice corrosion resistance. Metall. Mater. Trans. A Phys. Metall. Mater. Sci. 2010, 41, 2022-2032. [CrossRef]

18. Balaraju, J.N.; Sankara Narayanan, T.S.N.; Seshadri, S.K. Evaluation of the corrosion resistance of electroless Ni-P and Ni-P composite coatings by electrochemical impedance spectroscopy. J. Solid State Electrochem. 2001, 5, 334-338. [CrossRef]

19. Ono, S.; Tsuge, H.; Nishi, Y.; Hirano, S.I. Improvement of corrosion resistance of metals by an environmentally friendly silica coating method. J. Sol-Gel Sci. Technol. 2004, 29, 147-153. [CrossRef]

20. Li, G.; Zhang, L.; Cai, F.; Yang, Y.; Wang, Q.; Zhang, S. Characterization and corrosion behaviors of TiN/TiAlN multilayer coatings by ion source enhanced hybrid arc ion plating. Surf. Coat. Technol. 2019, 366, 355-365. [CrossRef]

21. Tang, P.T.; Watanabet, T.; Andersen, J.E.T.; Bech-Nielsen, G. Improved corrosion resistance of pulse plated nickel through crystallisation control. J. Appl. Electrochem. 1995, 25, 347-352. [CrossRef]

22. Kashyzadeh, K.R.; Arghavan, A. Study of the effect of different industrial coating with microscale thickness on the CK45 steel by experimental and finite element methods. Strength Mater. 2013, 45, 748-757. [CrossRef]

23. Bagherifard, S.; Beretta, N.; Monti, S.; Riccio, M.; Bandini, M.; Guagliano, M. On the fatigue strength enhancement of additive manufactured AlSi10Mg parts by mechanical and thermal post-processing. Mater. Des. 2018, 145, 28-41. [CrossRef]

24. Maleki, E.; Bagherifard, S.; Razavi, S.M.J.; Riccio, M.; Bandini, M.; du Plessis, A.; Berto, F.; Guagliano, M. Fatigue behaviour of notched laser powder bed fusion AlSi10Mg after thermal and mechanical surface post-processing. Mater. Sci. Eng. A 2022, 829, 142145. [CrossRef]

25. Maleki, E.; Bagherifard, S.; Sabouri, F.; Bandini, M.; Guagliano, M. Hybrid thermal, mechanical and chemical surface posttreatments for improved fatigue behavior of laser powder bed fusion AlSi10Mg samples with notched geometry. Surf. Coat. Technol. 2021, 430, 127962. [CrossRef]

26. Razavi, S.M.J.; Van Hooreweder, B.; Berto, F. Effect of build thickness and geometry on quasi-static and fatigue behavior of Ti-6Al-4V produced by Electron Beam Melting. Addit. Manuf. 2020, 36, 101426. [CrossRef]

27. Solberg, K.; Berto, F. Notch-defect interaction in additively manufactured Inconel 718. Int. J. Fatigue 2019, 122, 35-45. [CrossRef]

28. Kahlin, M.; Ansell, H.; Moverare, J.J. Fatigue behaviour of notched additive manufactured Ti6Al4V with as-built surfaces. Int. J. Fatigue 2017, 101, 51-60. [CrossRef]

29. Nicoletto, G. INFLUENCE OF ROUGH AS-BUILT SURFACES ON SMOOTH AND NOTCHED FATIGUE BEHAVIOR OF L-PBF AlSi10Mg. Addit. Manuf. 2020, 34, 101251. [CrossRef]

30. Uzan, N.E.; Ramati, S.; Shneck, R.; Frage, N.; Yeheskel, O. On the effect of shot-peening on fatigue resistance of AlSi10Mg specimens fabricated by additive manufacturing using selective laser melting (AM-SLM). Addit. Manuf. 2018, 21, 458-464. [CrossRef]

31. Maleki, E.; Unal, O.; Bandini, M.; Guagliano, M.; Bagherifard, S. Individual and synergistic effects of thermal and mechanical surface post-treatments on wear and corrosion behavior of laser powder bed fusion AlSi10Mg. J. Mater. Process. Technol. 2021, 302, 117479. [CrossRef]

32. Maleki, E.; Bagherifard, S.; Sabouri, F.; Guagliano, M. Effects of hybrid post-treatments on fatigue behaviour of notched LPBF AlSi10Mg: Experimental and deep learning approaches. Procedia Struct. Integr. 2021, 34, 141-153. [CrossRef]

33. Genna, S.; Ucciardello, N. A thermographic technique for in-plane thermal diffusivity measurement of electroplated coatings. Opt. Laser Technol. 2019, 113, 338-344. [CrossRef]

34. Arghavan, A.; Kashyzadeh, K.R.; Asfarjani, A.A. Investigating effect of industrial coatings on fatigue damage. Proc. Appl. Mech Mater. 2011, 87, 230-237. [CrossRef]

35. Weldon, D.G. Failure Analysis of Paints and Coatings: Revised Edition; Wiley: Hoboken, NJ, USA, 2009 ; ISBN 9780470697535.

36. Karger-Kocsis, J. Paints, coatings and solvents. Compos. Sci. Technol. 1994, 51, 613-614. [CrossRef]

37. Zadeh, M.K.; Yeganeh, M.; Shoushtari, M.T.; Esmaeilkhanian, A. Corrosion performance of polypyrrole-coated metals: A review of perspectives and recent advances. Synth. Met. 2021, 274, 116723. [CrossRef]

38. Cha, S.C.; Erdemir, A. Coating Technology for Vehicle Applications; Springer: New York, NY, USA, 2015; ISBN 9783319147710.

39. Kovář́k, O.; Haušild, P.; Čapek, J.; Medřický, J.; Siegl, J.; Mušálek, R.; Pala, Z.; Curry, N.; Björklund, S. Resonance bending fatigue testing with simultaneous damping measurement and its application on layered coatings. Proc. Int. J. Fatigue 2016, 82, 300-309. [CrossRef]

40. Yang, X.; Li, S.; Qi, H. Effect of MCrAlY coating on the low-cycle fatigue behavior of a directionally solidified nickel-base superalloy at different temperatures. Int. J. Fatigue 2015, 75, 126-134. [CrossRef]

41. Maleki, E. Artificial neural networks application for modeling of friction stir welding effects on mechanical properties of 7075-T6 aluminum alloy. Proc. IOP Conf. Ser. Mater. Sci. Eng. 2015, 103, 012034. [CrossRef]

42. Maleki, N.; Kashanian, S.; Maleki, E.; Nazari, M. A novel enzyme based biosensor for catechol detection in water samples using artificial neural network. Biochem. Eng. J. 2017, 128, 1-11. [CrossRef]

43. Maleki, E.; Unal, O. Optimization of Shot Peening Effective Parameters on Surface Hardness Improvement. Met. Mater. Int. 2020, 27, 3173-3185. [CrossRef]

44. Jahanshahi, M.; Maleki, E.; Ghiami, A. On the efficiency of artificial neural networks for plastic analysis of planar frames in comparison with genetic algorithms and ant colony systems. Neural Comput. Appl. 2016, 28, 3209-3227. [CrossRef] 
45. Maleki, E.; Unal, O.; Reza Kashyzadeh, K. Fatigue behavior prediction and analysis of shot peened mild carbon steels. Int. J. Fatigue 2018, 116, 48-67. [CrossRef]

46. Kong, Y.S.; Abdullah, S.; Schramm, D.; Omar, M.Z.; Haris, S.M. Optimization of spring fatigue life prediction model for vehicle ride using hybrid multi-layer perceptron artificial neural networks. Mech. Syst. Signal Process. 2019, 122, 597-621. [CrossRef]

47. Maleki, E.; Kashyzadeh, K.R.R. Effects of the hardened nickel coating on the fatigue behavior of CK45 steel: Experimental, finite element method, and artificial neural network modeling. Iran. J. Mater. Sci. Eng. 2017, 14, 81-99. [CrossRef]

48. Maleki, E.; Unal, O. Fatigue limit prediction and analysis of nano-structured AISI 304 steel by severe shot peening via ANN. Eng. Comput. 2020, 37, 2663-2678. [CrossRef]

49. Sbarufatti, C.; Manes, A.; Giglio, M. Performance optimization of a diagnostic system based upon a simulated strain field for fatigue damage characterization. Mech. Syst. Signal Process. 2013, 40, 667-690. [CrossRef]

50. Fathalla, E.; Tanaka, Y.; Maekawa, K. Remaining fatigue life assessment of in-service road bridge decks based upon artificial neural networks. Eng. Struct. 2018, 171, 602-616. [CrossRef]

51. Jimenez-Martinez, M.; Alfaro-Ponce, M. Fatigue damage effect approach by artificial neural network. Int. J. Fatigue 2019, 124, 42-47. [CrossRef]

52. Venkatesh, V.; Rack, H.J. Neural network approach to elevated temperature creep-fatigue life prediction. Int. J. Fatigue 1999, 21, 225-234. [CrossRef]

53. Vassilopoulos, A.P.; Georgopoulos, E.F.; Dionysopoulos, V. Artificial neural networks in spectrum fatigue life prediction of composite materials. Int. J. Fatigue 2007, 29, 20-29. [CrossRef]

54. Figueira Pujol, J.C.; Andrade Pinto, J.M. A neural network approach to fatigue life prediction. Int. J. Fatigue 2011, $33,313-322$. [CrossRef]

55. Barbosa, J.F.; Correia, J.A.F.O.; Júnior, R.C.S.F.; de Esus, A.M.P. Fatigue life prediction of metallic materials considering mean stress effects by means of an artificial neural network. Int. J. Fatigue 2020, 135, 105527. [CrossRef]

56. Abdalla, J.A.; Hawileh, R. Modeling and simulation of low-cycle fatigue life of steel reinforcing bars using artificial neural network. Proc. J. Frankl. Inst. 2011, 348, 1393-1403. [CrossRef]

57. Amiri, N.; Farrahi, G.H.; Kashyzadeh, K.R.; Chizari, M. Applications of ultrasonic testing and machine learning methods to predict the static \& fatigue behavior of spot-welded joints. J. Manuf. Process. 2020, 52, 26-34. [CrossRef]

58. Cervera, M.; Barbat, G.B.; Chiumenti, M.; Wu, J.Y. A Comparative Review of XFEM, Mixed FEM and Phase-Field Models for Quasi-brittle Cracking. Arch. Comput. Methods Eng. 2021, 1-75. [CrossRef]

59. Pandey, V.B.; Singh, I.V.; Mishra, B.K.; Ahmad, S.; Venugopal Rao, A.; Kumar, V. A new framework based on continuum damage mechanics and XFEM for high cycle fatigue crack growth simulations. Eng. Fract. Mech. 2019, 206, 172-200. [CrossRef]

60. Bui, T.Q.; Hu, X. A review of phase-field models, fundamentals and their applications to composite laminates. Eng. Fract. Mech. 2021, 248, 107705. [CrossRef]

61. Lo, Y.S.; Borden, M.J.; Ravi-Chandar, K.; Landis, C.M. A phase-field model for fatigue crack growth. J. Mech. Phys. Solids 2019, 132, 103684. [CrossRef]

62. Maleki, E.; Unal, O. Shot Peening Process Effects on Metallurgical and Mechanical Properties of 316 L Steel via: Experimental and Neural Network Modeling. Met. Mater. Int. 2019, 27, 262-276. [CrossRef]

63. Maleki, E.; Bagherifard, S.; Guagliano, M. Application of artificial intelligence to optimize the process parameters effects on tensile properties of Ti-6Al-4V fabricated by laser powder-bed fusion. Int. J. Mech. Mater. Des. 2021, 1-24. [CrossRef]

64. Feng, S.; Zhou, H.; Dong, H. Using deep neural network with small dataset to predict material defects. Mater. Des. 2019, 162, 300-310. [CrossRef]

65. Maleki, E.; Unal, O.; Guagliano, M.; Bagherifard, S. Analysing the Fatigue Behaviour and Residual Stress Relaxation of Gradient Nano-structured 316L Steel Subjected to the Shot Peening via Deep Learning Approach. Met. Mater. Int. 2021, $28,112-131$. [CrossRef]

66. Kalayci, C.B.; Karagoz, S.; Karakas, Ö. Soft computing methods for fatigue life estimation: A review of the current state and future trends. Fatigue Fract. Eng. Mater. Struct. 2020, 43, 2763-2785. [CrossRef]

67. Abiodun, O.I.; Jantan, A.; Omolara, A.E.; Dada, K.V.; Mohamed, N.A.E.; Arshad, H. State-of-the-art in artificial neural network applications: A survey. Heliyon 2018, 4, e00938. [CrossRef] [PubMed]

68. Tao, C.; Zhang, C.; Ji, H.; Qiu, J. Fatigue damage characterization for composite laminates using deep learning and laser ultrasonic. Compos. Part B Eng. 2021, 216, 108816. [CrossRef]

69. Lee, H.; Lim, H.J.; Skinner, T.; Chattopadhyay, A.; Hall, A. Automated fatigue damage detection and classification technique for composite structures using Lamb waves and deep autoencoder. Mech. Syst. Signal Process. 2021, 163, 108148. [CrossRef]

70. Rovinelli, A.; Sangid, M.D.; Proudhon, H.; Ludwig, W. Using machine learning and a data-driven approach to identify the small fatigue crack driving force in polycrystalline materials. Npj Comput. Mater. 2018, 4, 35. [CrossRef]

71. Zhan, Z.; Li, H. Machine learning based fatigue life prediction with effects of additive manufacturing process parameters for printed SS 316L. Int. J. Fatigue 2021, 142, 10594. [CrossRef]

72. Chen, J.; Liu, Y. Fatigue modeling using neural networks: A comprehensive review. Fatigue Fract. Eng. Mater. Struct. 2021. [CrossRef] 
73. Reza Kashyzadeh, K.; Maleki, E. Experimental Investigation and Artificial Neural Network Modeling of Warm Galvanization and Hardened Chromium Coatings Thickness Effects on Fatigue Life of AISI 1045 Carbon Steel. J. Fail. Anal. Prev. 2017, 17, 1276-1287. [CrossRef]

74. Maleki, E.; Maleki, N. Artificial Neural Network Modeling of Pt/C Cathode Degradation in PEM Fuel Cells. J. Electron. Mater. 2016, 45, 3822-3834. [CrossRef]

75. Maleki, E.; Mirzaali, M.J.; Guagliano, M.; Bagherifard, S. Analyzing the mechano-bactericidal effect of nano-patterned surfaces on different bacteria species. Surf. Coat. Technol. 2020, 408, 126782. [CrossRef]

76. Maleki, E.; Unal, O.; Reza Kashyzadeh, K. Surface layer nanocrystallization of carbon steels subjected to severe shot peening: Analysis and optimization. Mater. Charact. 2019, 157, 109877. [CrossRef] 